\title{
A new system for classification of chlorophyll mutations
}

\author{
S. MUSZYŃSKI
}

The first effort to classify the chlorophyll mutations was made by De Haan (1933), who distinguished chlorophyll defects due to Mendelian and to others factors. The former were divided into two sub-classes: one-coloured and twocoloured. The one-coloured sub-class included such types as albina, xantha, chlorina, virescens, lutescens and mutations occurring only in heterozygous state. The twocoloured group contained the following forms: maculata, maculata due to labile genes, and albomarginata.

Eyster (1934) described ten types of chlorophyll mutations:

1. albina (albina)

2. virescent (virescens)

3. yellowish seedlings (lutea)

4. pale green (chlorotica and chlorina)

5. yellow-white (lutescens, albescens)

6. golden (aurea)

7. white leaf base (albina-basalis)

8. dotted patterns (maculata)

9. striped patterns (striata)

10. banded patterns (transvirgata)

The first commonly accepted classification was that of Gustafsson (1940), who distinguished nine classes and several subclasses as follows:

1. albina: no carotenoiids or chlorophylls are formed;

2. xantha: carotenoids prevail or chlorophylls are not produced;

3. alboviridis: different colours at the base and tip of the leaf;

a) alboxantha: base yellow, tip white;

b) xanthalba: base white or faintly coloured, tip yellowish;

c) viridoalbina: base white, tip more or less greenish or yellowish green;

d) alboviridis (sensu stricto): base green, tip white;

4. viridis: a heterogeneous group, characterized by uniformly yellowish-green or light-green colour occurring already at seedling stage;

a) virescens: the light green uniform colour gradually changes to dark green; finally the colour becomes almost normal;

b) chlorina: yellowish-green colours generally prevailing throughout life, or darkening somewhat; 
c) lutescens: the original green pigments are destroyed, the leaves wither and turn yellowish;

d) albescens: like c) but even more extreme; the original colours change to white or yellowish-white;

5. tigrina: transverse destruction of pigments;

6. striata: longitudal stripes of white or yellow colour;

7. maculata: chlorophyll and/or carotin destruction in the form of dots distributed over the leaf;

8. unidentified mutations;

9. plasm mutations.

Since the Gustafsson's system was published, several new mutant types were described. Although the system of Gustafsson is very convenient in use, it should be modified according to the present state of knowledge on chlorophyll mutations.

Several efforts were made in this direction. Haensel (1960) divided chlorophyll mutations into two groups using Gustafsson's types as sub-groups:

I. plants are uniformly or almost uniformly coloured; the following types are included: albina, xantha, viridis;

II. plants or leaves on a plant are not uniformly coloured; this class includes following types: alboxantha, xanthalba, alboviridis, viridoalbina, xanthaviridis, tigrina, striata.

Another effort was made by Blixt (1961) who based his classification of chlorophyll mutations on the system of Lamprecht (1960). The latter author tried to describe all types of green colouration which exist among higher plants.

$\mathrm{He}$ created a very large and complicated system which is difficult in application and thus of little practical value. Blixt as well as Lamprecht introduced many names to denote various types of chlorophyll mutations. The names are compounds of two or three and even more words what makes it difficult to keep in mind all of them.

Blixt distinguished three main classes of chlorophyll mutations, namely:

I. chlorovegatus: only viable mutations are included;

II. chlorodefectus: forms showing chlorophyll defects;

III. anthocyan: forms containing also anthocyan pigments.

Each of the main groups is in turn divided into sub-groups which are further divided into sub-sub-groups.

As pointed out, the system of Blixt is too complicated for practical use.

It was the aim of the proposed classification to modify the system of Gustafsson on the one hand, and to simplify that of Blixt on the other. An effort was made to give uniform endings to the names of mutation types within a class. Each class has its specific ending indicating to which class a given type of chlorophyll defect belongs.

Five classes of chlorophyll mutations are distinguished. The first class includes chlorophyll-less mutations, the second-those with reduced chlorophyll content. The third class includes forms which change their phenotypic appearance during 
the growth and development of plants. The fourth class is composed of chlorophyll mutations in which normal cells are mixed with abnormal ones. The last class includes bi- or more coloured forms; this class corresponds to the alboviridis group of Gustafsson.

Proposed classification:

I. defecta: forms without chlorophyll;

a) albina: cotyledons white, no chlorophyll or carotenoids are formed;

b) xanthina: cotyledons yellow, only carotenoids are formed, no chlorophyll present;

II. chlorotica: forms with reduced chlorophyll content;

a) lutina: yellow leaves with marked prevalence of carotenoids;

b) chlorina: yellow-green leaves, more chlorophylls than carotenoids;

c) viridina: pale-green colour;

III. transescens: mutants whose phenotypic expression changes during the growth and development of plants;

1. chlorotescens: changing from normal green to abnormal colour;

a) virina-albescens: green changing to white;

b) virina-xanthescens: green changing to yellow;

c) virina-lutescens: green changing to greenish-yellow;

d) virina-chlorescens: green changing to yellowish-green;

e) virina-viridescens: green changing to pale green;

2. virescens: abnormal colour changing to normal green:

a) albina-virescens: white changing to green;

b) xanthina-virescens: yellow changing to green;

c) lutina-virescens: greenish-yellow changing to green;

d) chlorina-virescens: yellowish-green changing to green;

e) viridina-virescens: pale green changing to green;

3. variabilis: abnormal forms changing to other abnormal ones, e.g. lutinamaculata etc.

IV. variegata: leaves are composed of intermixed normal and abnormal tissues;

a) maculata: small spots of abnormal tissue;

b) irregulare: spots formed of abnormal tissue are of irregular sizes and shapes;

c) striata: longitudinal stripes of abnormal tissue;

d) tigrina: transverse stripes of abnormal tissue;

e) marginata: only margines of leaves are abnormal;

f) costata: abnormal tissue along nerves of the leaves;

V. diversicata: different colours at the base and tip of the leaves;

a) alboxanthina: base yellow, tip white;

b) xanthalbina: base white, tip yellowish;

c) viridoalbina: base white, tip greenish or green;

d) alboviridis: base green, tip white. 


\section{REFERENCES}

Blixt S., 1961, Agri Horti. Genet. 19:402-447;

Eyster W. H., 1934, Bibliogr. Genet. 11:186-392;

Gustafsson A., 1940, Lunds Univ. Arsskr. N. F. 36:1-40;

Haan H. de, 1933, Bibliogr. Genet. 10:357-416;

Haensel H., 1960, Z. Vererbungsl. 91:358-372;

Lamprecht H., 1960, Agri Horti. Genet. 18:135-168.

Nowy system klasyfikacji mutantów chlorofilowych

\section{Streszczenie}

Ze względu na stale powiększającą się liczbę mutantów chlorofilowych, autor zaproponował nowy system klasyfikacji, oparty na podstawach fizjologiczno-morfologicznych. W systemie tym wyróżniono 5 następujących grup:

1. Mutanty pozbawione zupełnie chlorofilu,

2. Osobniki o zredukowanej zawartości chlorofilu,

3. Mutacje zatracające charakterystyczne zmiany chlorofilowe w trakcie wegetacji,

4. Osobniki zbudowane $\mathrm{z}$ tkanek normalnych i zmutowanych,

5. Mutacje o różnorodnych zmianach występujących jednocześnie na tych samych roślinach. 